\title{
Evaluation of Morphological Characteristics and Forage Biomass Yield of Five Selected Wheat Cultivars for Ruminant Livestock Nu- trition in Northern Pakistan
}

\author{
Syed Muhammad Sulaiman, Nazir Ahmad and Nazir Ahmad Khan*
}

Department of Animal nutrition, the University of Agriculture, Peshawar, Khyber Pakhtunkbwa, Pakistan.

\begin{abstract}
This research study evaluated the genetic variation in forage biomass yield, morphological characteristic, forage nutritional value and digestibility among five selected wheat genotypes. The five cultivars, namely, Pir Sabaq (PS)-15, Bakhtawar-92, PS-2000, National Agriculture Research Council (NARC)-11 and Zam-04 were grown in 12 replicate plots $(6 \mathrm{~m} \times 10 \mathrm{~m})$, that were blocked in three fields according to Randomized Complete Block Design. Uniform field preparation, irrigation, weeds control and standard agronomic practices were applied to all plots. For forage yield, morphological and quality evaluation, samples were collected from randomly selected one-meter long strip of two consecutive rows of each plot at feekes stages 7 to 8, when the second last leaf was visible. The collected samples were immediately weighed, and 10 plants were subsampled from each sample for morphological evaluation. Ten plants were weighed and separated into stem and leaves portion, subsequently weighed and analysed for dry matter (DM) content. The remaining samples were air dried, ground and analysed for chemical composition and in vitro digestibility (IVDMD) and in vitro gas production (IVGP). The results revealed large variability $(\mathrm{P}<0.001)$ in $\mathrm{DM}$ yield, ranging from 1943 to $2763 \mathrm{~kg} / \mathrm{ha}$. There was also greater variability $(\mathrm{P}<0.001)$ in morphological characteristics among the wheat cultivars. The percentage of leaves varied from 0.33 to $0.45 \%$ and leaf to stem ratio varied from 0.47 to 0.84 . There was also marked variation $(\mathrm{P}<0.001)$ in the plant height, ranging from 68.7 to $79.3 \mathrm{~cm}$. The chemical composition showed large range $(\mathrm{P}<0.001)$ among the five wheat cultivars, the ash content varied from 6.01 to $7.90 \%$, crude protein (CP) from 8.71 to $12.40 \%$ and crude fat (CFat) from 1.02 to $3.26 \%$. The neutral detergent fibre (NDF) from 43.2 to $44.7 \%$. The $I V D M D$ varied from 48.4 to $58.9 \%$ and $I V G P$ varied from 110 to $172 \mathrm{~mL} / \mathrm{g}$ organic matter. Among the five wheat cultivars Bakhtawar-92 had maximum DM yield (2747 kg/ha), proportion of leaves (45\%), CP (12.4\%), IVDMD (58.9\%) and $I V G P$ $(172 \mathrm{~mL} / \mathrm{g}$ organic matter), and minimum portion of stem $(55 \%)$ and NDF (43.2\%), and thus supported greater yield of high quality wheat fodder. Other cultivars which combined similar desirable characteristic were ranked in order of merit as PS-15, PS-2000, NARC-11 and Zam-04.

Received | May 19, 2021; Accepted | June 21, 2021; Published | August 03, 2021

*Correspondence | Nazir Ahmad Khan, Department of Animal nutrition, the University of Agriculture, Peshawar, Khyber Pakhtunkhwa, Pakistan; Email: nazir.khan@aup.edu.pk

Citation | Sulaiman, S.M., A. Nazir and N.A. Khan. 2021. Evaluation of morphological characteristics and forage biomass yield of five selected wheat cultivars for ruminant livestock nutrition in northern Pakistan. Sarbad Journal of Agriculture, 37(3): 1073-1080.

DOI | https://dx.doi.org/10.17582/journal.sja/2021/37.3.1073.1080

Keywords | Wheat cultivars, Biomass yield, Morphological characteristics, Nutritional value, In vitro digestibility, In vitro gas production
\end{abstract}

\section{Introduction}

$\mathrm{P}$ akistan is the fourth largest milk producing country in the world, and milk and milk products play an important role in national Gross Domestic Products (GDP), particularly in livelihood and economy of rural population. However, there is still an increasing demand for milk and milk products, 
and it is expected to increase further due to increasing population and rising income levels (Sulaiman et al., 2021). The rising demand for milk and milk products has led to rapid intensification of the dairy industry over the past decade, which in the face of shrinking agricultural land, demands for efficient utilization of available land and feed resources. Currently, the lack of good quality forages, particularly during the prolonged winter and summer scarcity periods severely impede productivity and profitability of dairy animals in the country (Habib et al., 2016; Sulaiman et al., 2021). In this context, development of high yielding and highly digestible forage varieties and optimizing their utilization in dairy rations is one of the main cross cutting issues to be researched.

Good quality forages are available in sufficient quantity only in few months of the year, and in the rest of the year ruminants are fed with crop residues, low quality hay or grazed on low quality pastures in the rangelands under the predominant small and medium scale production systems. These low-quality forages often do not fulfil requirements for milk production, particularly of the high producing animals. The need for good quality forages is particularly high during extreme winter and summer period. For meeting this deficiency during winter season, many countries are using wheat for providing early cut during the peak winter season (Northup, 2010; MacKown et al., 2011). Moreover, traditionally, in the Khyber Pakhtunkhwa province of Pakistan mix cropping of wheat with berseem (Trifolium alexandrinum), shaftal (Trifolium resupinatum) and vetch (Viciasativa) is practiced to provide an early, stable cut of good quality forage during winter scarcity period.

Wheat is generally grown for cereal grain purpose; however, little attention has been given to improvement of its forage quality (Cash et al., 2007). The specific varieties of wheat affect not only the grain yield but also the nutritional quality of wheat forage and straws (Kim et al., 2016; Bezabih et al., 2018). It has been reported that wheat genotypes, which have more height have more long lean leaves proportion $(142-152 \mathrm{~cm})$, produces higher yields and more nutritious biomass of both forage and straw (Capstaff and Miller, 2018). Research in the US (Kim and Anderson, 2014) have shown large variation in forage nutritional value and neutral detergent fibre (NDF) digestibility among wheat cultivars. The present study was therefore deigned to exploit the genetic variation in forage biomass yield, morphological characteristic, nutritional value and digestibility among selected promising wheat cultivars for production of quality forage.

\section{Materials and Methods}

\section{Experimental design, land preparation sowing and crop management}

The experiment was conducted at the research fields of the University of Agriculture, Peshawar Pakistan with the collaboration of Cereal Crop Research Institute (CCRI), Pirsabaq, Nowshehra, Khyber PakhtunKhwa, Pakistan. The five promising wheat cultivars were grown under uniform standard agronomical conditions. Seeds (3 $\mathrm{kg}$ of each cultivar) of the wheat cultivars were provided by CCRI. Before sowing, twelve subsamples (150 g) were collected and properly labelled for sowing in the twelve replicate plots. The seeds weight for the plot was calculated based on seed rate, 1000 seeds weight and plot size. Before sowing, farmyard manure was applied at a rate of 4 tons/jerib based on soil nutrient profile. The field was ploughed with cultivator two times followed by rotavator for a fine seedbed preparation. The 150 $\mathrm{g}$ seeds per plot were sown in rows with a row to row distance of $30 \mathrm{~cm}$. Four replicate plots of each cultivar were blocked in 3 replicate fields according to a randomized complete block design. The nitrogen fertilizer was applied at the rate of $30 \mathrm{~kg} / \mathrm{jerib}$, while phosphorus and potassium were provided at the rate of $30 \mathrm{~kg} / \mathrm{jerib}$. All plots were irrigated two weeks after the germination of seeds, and then weekly. However, the interval was adjusted according to weather conditions.

\section{Sampling}

For evaluation of forage yield, morphological and quality characteristic, samples were collected from randomly selected one-meter long strip of two consecutive rows of each plot at feeks growth stage 7 to 8 , when the second last leaf was visible. The exterior $1 \mathrm{~m}$ area of each plot was excluded from sampling. The samples were covered with plastic bags to protect it from air and direct sunlight. The samples were immediately weighed and analysed for dry matter (DM) content. Then 10 randomly selected plants from each sample were subsampled, and weight and height of individual plant was recorded. The leaves and stem portion were separated manually and weighed and analysed for DM content at the laboratory of Animal 
Nutrition, the University of Agriculture Peshawar, Pakistan.

\section{Chemical analysis}

The air-dried ground ( $1 \mathrm{~mm}$ size $)$ samples were analysed for nutrient composition of wheat fodder, cell wall content and in vitro dry matter digestibility (IVDMD). The contents of DM (method 930.15), ash (method 942.05), crude protein (CP; method 984.13) and ADF (method 973.18) were analysed according to Association of Official Analytical Chemists (AOAC, 1995). The NDF content was analysed using the method of Van Soest et al. (1991).

In vitro $\mathrm{DMD}$ was determined using the commonly used two stage digestibility procedure of Tilly and Terry (1957) at the laboratory of Animal Nutrition, the University of Agriculture Peshawar. The in vitro gas production (IVGP) was analysed using fully automated gas production apparatus (Cone and Engeles, 1995) at the laboratory of Animal Nutrition, Wageningen University, the Netherlands.

\section{Statistical analysis}

Data on the effect of wheat cultivar on forage biomass yield, morphological characteristics, chemical composition, $I V \mathrm{DMD}$ and $I V G P$ were analysed using the PROCMIXED procedure of SAS (SAS Inst., Inc., Cary, NC).

$$
R i j=\mu+W G i+\epsilon_{i j}
$$

Where, $\mathrm{Rij}$ is response variable; $\mu$ is the overall mean; WGi is the fixed effect of wheat genotype and $C_{\mathrm{ij}}$ is random error. For parameters with significant $(\mathrm{P}$ $<0.05)$ differences, pair-wise differences among the means were computed using Tukey-Kramer test. The "pdmix 800" SAS macro program was used to obtain different letters for means with significant $(\mathrm{P}<0.05)$ differences.

\section{Results and Discussion}

Mean, minimum and maximum values biomass yield, morphological characteristics, chemical composition, IVDMD and IVGP of the studied wheat cultivars are summarized in Table 1 . The DM yield varied from 1943 to $2763 \mathrm{~kg} / \mathrm{ha}$, plant height from 68.7 to $79.3 \mathrm{~cm}$ and leaf to stem ratio from 0.47 to 0.84 . There was also large range in the content of $\mathrm{CP}$ (8.71 to $12.4 \% \mathrm{DM}$ ), NDF (43.2 to $44.7 \% \mathrm{DM}$ ) and crude fat (1.02 to $3.26 \%)$. This variation in chemical composition was also reflected in large variation in the values of $72 \mathrm{~h}$ total IVGP (110 to $172 \mathrm{~mL} / \mathrm{g}$ organic matter (OM) and IVDMD (48.4 to 58.9\%).

Table 1: Mean, minimum and maximum value of biomass yield, morphological characteristics, chemical composition, in vitro digestibility and in vitro gas production of wheat cultivars.

\begin{tabular}{|c|c|c|c|c|}
\hline Trait & Unit & $\begin{array}{l}\text { Average } \\
\text { value }\end{array}$ & $\begin{array}{l}\text { Min- } \\
\text { imum } \\
\text { value }\end{array}$ & $\begin{array}{l}\text { Max- } \\
\text { imum } \\
\text { value }\end{array}$ \\
\hline \multicolumn{5}{|l|}{ Yield } \\
\hline Fresh biomass yield & $\mathrm{kg} / \mathrm{ha}$ & 12835 & 11166 & 15250 \\
\hline Dry matter content & $\%$ & 19.1 & 17.4 & 22.1 \\
\hline Dry matter yield & $\mathrm{kg} / \mathrm{ha}$ & 2449.3 & 1943.0 & 2762.5 \\
\hline \multicolumn{5}{|c|}{ Morphological Characteristics } \\
\hline Proportion leaves & $\%$ & 0.40 & 0.33 & 0.45 \\
\hline Proportion stem & $\%$ & 0.60 & 0.54 & 0.67 \\
\hline Leaf: system ratio & & 0.68 & 0.47 & 0.84 \\
\hline Plant height & $\mathrm{cm}$ & 74.4 & 68.7 & 79.3 \\
\hline \multicolumn{5}{|l|}{ Chemical composition } \\
\hline Dry matter & $\%$ & 19.1 & 17.4 & 22.1 \\
\hline Ash & $\%$ & 6.9 & 6.0 & 7.9 \\
\hline Crude protein & $\%$ & 10.5 & 8.70 & 12.4 \\
\hline Crude fat & $\%$ & 1.8 & 1.0 & 3.3 \\
\hline Neutral detergent fibre & $\%$ & 44.0 & 42.4 & 44.7 \\
\hline Acid detergent fibre & $\%$ & 31.1 & 29.4 & 32.2 \\
\hline \multicolumn{5}{|l|}{ Digestibility } \\
\hline IVDMD & $\%$ & 51.5 & 48.5 & 58.9 \\
\hline IVGP & $\mathrm{mL} / \mathrm{g} \mathrm{OM}$ & 127.7 & 76.6 & 172 \\
\hline
\end{tabular}

IVDMD: in vitro dry matter digestibility; IVGP: in vitro gas production; OM: organic matter.

Data in Table 2 shows that the cultivars significantly affected fresh biomass yield $(\mathrm{P}<0.001), \mathrm{DM}$ yield $(\mathrm{P}<0.001)$ and morphological characteristics $(\mathrm{P}<$ $0.001)$ of wheat forage. The highest $(\mathrm{P}<0.05) \mathrm{DM}$ yield was recorded for PS-15 (2763 kg/ha) and lowest $(\mathrm{P}<0.05)$ for Zam-04 $(1943 \mathrm{~kg} / \mathrm{ha})$. The greater $(\mathrm{P}<$ $0.05)$ leaf: stem ratio was recorded for Bakhtawar-92 (0.84) and lowest $(\mathrm{P}<0.05)$ for Zam-04 (0.47). The highest $(\mathrm{P}<0.05)$ plant height was recorded for PS$15(79.3 \mathrm{~cm})$ and lowest was recorded for PS-2000 $(68.7 \mathrm{~cm})$.

Table 3 presents data on the effect of cultivars on chemical profile, IVDMD and IVGP of wheat forages. There was large variation in all measured chemical components $(\mathrm{P}<0.001)$, IVDMD $(\mathrm{P}<$ 
$0.001)$ and $72 \mathrm{~h}$ cumulative IVGP $(\mathrm{P}<0.001)$ among the evaluated wheat cultivars. Means comparison revealed that cultivars Bakhtawar-92 had the highest $(\mathrm{P}<0.05)$ contents of $\mathrm{CP}(12.4 \%), I V D M D(58.9 \%)$ and $72 \mathrm{~h}$ cumulative IVGP $(172 \mathrm{~mL} / \mathrm{g} \mathrm{OM})$ and lowest $(\mathrm{P}<0.05)$ contents of NDF $(43.2 \%)$ and ADF (30.2\%). Cultivars NARC-11 had lowest $(\mathrm{P}<0.05)$ content of $\mathrm{CP}(8.71 \%)$ and highest content of NDF (44.5\%) and $\mathrm{ADF}$ (30.2\%), which resulted lowest values of $I V \mathrm{DMD}(48.5 \%)$ and $72 \mathrm{~h}$ cumulative IVGP (76.6 mL/g OM).

Table 2: Variation in fresh biomass yield, dry matter yield and morphological characteristics of the wheat cultivars.

\begin{tabular}{|c|c|c|c|c|c|c|}
\hline & $\begin{array}{l}\text { Fresh } \\
\text { yield } \\
\text { (kg/ha) }\end{array}$ & $\begin{array}{l}\text { DM } \\
\text { yield } \\
\text { (kg/ha) }\end{array}$ & PL\% & PS\% & L: S & $\begin{array}{l}\text { Plant } \\
\text { height } \\
\text { (cm) }\end{array}$ \\
\hline \multicolumn{7}{|c|}{ Wheat cultivars } \\
\hline PS-15 & $12500^{a}$ & $2763^{a}$ & $0.45^{\mathrm{a}}$ & $0.55^{\mathrm{c}}$ & $0.79^{\mathrm{b}}$ & $79.3^{\mathrm{a}}$ \\
\hline Bakhtawar-92 & $13875^{b}$ & $2747^{\mathrm{ab}}$ & $0.44^{\mathrm{b}}$ & $0.56^{\mathrm{b}}$ & $0.84^{a}$ & $75.0^{\mathrm{ab}}$ \\
\hline NARC-11 & $15250^{\mathrm{ab}}$ & $2745^{\mathrm{b}}$ & $0.33^{c}$ & $0.66^{\mathrm{ab}}$ & $0.49^{c}$ & $72.9^{\mathrm{b}}$ \\
\hline PS-2000 & $11383^{c}$ & $2049^{c}$ & $0.44^{\mathrm{b}}$ & $0.55^{\mathrm{c}}$ & $0.81^{\mathrm{ab}}$ & $68.7^{\mathrm{c}}$ \\
\hline Zam-04 & $11167^{\mathrm{d}}$ & $1943^{d}$ & $0.33^{c}$ & $0.67^{\mathrm{a}}$ & $0.47^{c}$ & $76.1^{\mathrm{ab}}$ \\
\hline \multicolumn{7}{|l|}{ Significance } \\
\hline SEM & 98.3 & 34.5 & 0.02 & 0.02 & 0.04 & 1.45 \\
\hline $\mathrm{P}$-value & $* * *$ & $* * *$ & $* * *$ & $* * *$ & $* * *$ & $* * *$ \\
\hline
\end{tabular}

SEM: standard error mean; ***: $P<0.001 ; D M Y$ : dry matter yield; PL: percentage of leaves; PS: percentage of stem; L: S: leaf to stem ratio; $P H$ : plant height.

The time series data on cumulative gas production during $72 \mathrm{~h}$ rumen incubation in buffer-rumen fluid of the 5 selected wheat cultivars is shown in Figure 1. It is evident from Figure 1 that Bakhtawar-92 consistently produced higher volumes of gas during the $72 \mathrm{~h}$ in vitro rumen fermentation, followed by PS-15, while NARC 11 produced lowest amount of gas, particularly during 20-72 $\mathrm{h}$.

The productivity, profitability, and long termsustainability of livestock industry in Pakistan require the availability of good quality forage resources for the entire year, because forages are the cheaper and natural source of nutrients and energy for ruminant livestock (Sulaiman et al., 2021; Khan et al., 2020). Increasing the availability and consumption of forages will concurrently reduce the consumption of grains by ruminant livestock and as such reduce the growing competition of feed and food industries for grains.

In Pakistan wheat provide green forage during winter forage scarcity period, when warm-season grasses and legume forages growth are restricted by lower temperatures. Wheat is either grown as a dualpurposes (forage and grain production) crop or in mixture with other leguminous and non-leguminous fodder crops for more stable yield and quality fodder production during winter scarcity period. As a promising source for winter forage production (Kim and Anderson, 2016), screening of the current pool of traditional wheat cultivars for selection of wheat genotypes with high forage yield and nutritional value could minimize the animal production losses during the winter scarcity periods, particularly under the predominant small-scale production systems of the country.

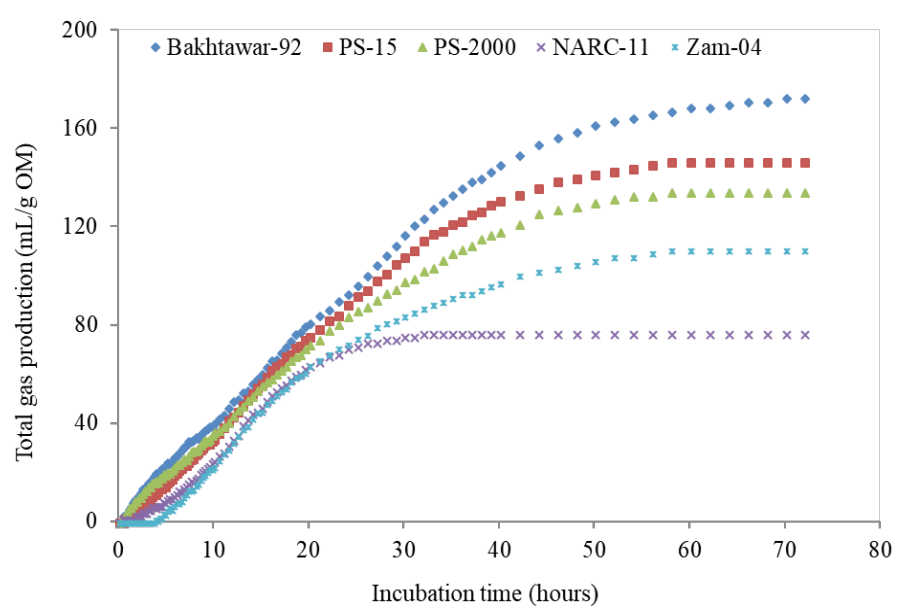

Figure 1: Cumulative gas volume of the five wheat cultivars during 72 b rumen incubation.

Results of this study showed a great variation in DM yield among the wheat cultivars, ranging from 1943 (Zam-04) to 2763 (PS-15) kg/ha. In the support of our results, Kim et al. (2016) recorded a large variation in DM yield (1260 to $4158 \mathrm{~kg} / \mathrm{ha}$ ) among wheat genotypes harvested at similar stage of maturity for forage production. Our results are in line with the finding of Bezabih et al. (2018), who found a significant variation in DM yield (10704 to $13607 \mathrm{~kg} /$ ha) among 25 wheat cultivars. Similarly, Shuja et al. (2009) and Bisht et al. (2008) recorded large variation in the DM yield among wheat genotypes (6518 to $13190 \mathrm{~kg} / \mathrm{ha}$ ).

The significant variation in morphological characteristics such as plant height and leaf: Stem ratio among the evaluated wheat cultivars reflects the variation in their chemical composition and digestibility. There was a large range (68.7 to 79.3 $\mathrm{cm})$ in the plant height among the wheat cultivars. 
Table 3: Fresh dry matter, chemical composition, in vitro dry matter digestibility and in vitro gas production of five commonly grown cultivars.

\begin{tabular}{|c|c|c|c|c|c|c|c|c|}
\hline \multirow[t]{2}{*}{ Wheat cultivars } & \multirow[t]{2}{*}{ DM } & \multicolumn{5}{|c|}{ Chemical compositions \%DM } & \multirow[t]{2}{*}{ IVDMD \% } & \multirow[t]{2}{*}{ IVGP } \\
\hline & & Ash & $\mathrm{CP}$ & CFat & NDF & $\mathrm{ADF}$ & & \\
\hline PS-15 & $22.1^{\mathrm{a}}$ & $7.9^{\mathrm{a}}$ & $10.6^{\mathrm{b}}$ & $1.2^{\mathrm{d}}$ & $43.2^{\mathrm{b}}$ & $31.8^{\mathrm{ab}}$ & $50.4^{\mathrm{ab}}$ & $146^{\mathrm{b}}$ \\
\hline Bakhtawar-92 & $19.8^{\mathrm{ab}}$ & $7.33^{\mathrm{b}}$ & $12.4^{\mathrm{a}}$ & $1.02^{\mathrm{d}}$ & $42.4^{\mathrm{c}}$ & $29.4^{c}$ & $58.9^{\mathrm{a}}$ & $172^{\mathrm{a}}$ \\
\hline NARC-11 & $18.0^{\mathrm{b}}$ & $6.3^{c}$ & $8.71^{\mathrm{d}}$ & $3.26^{\mathrm{a}}$ & $44.5^{\mathrm{ab}}$ & $30.2^{\mathrm{b}}$ & $48.5^{\mathrm{c}}$ & $76.6^{\mathrm{d}}$ \\
\hline PS-2000 & $18.0^{\mathrm{b}}$ & $6.01^{\mathrm{c}}$ & $11^{\mathrm{ab}}$ & $1.44^{c}$ & $44.7^{\mathrm{a}}$ & $32.2^{\mathrm{a}}$ & $50.6^{\mathrm{ab}}$ & $134^{c}$ \\
\hline Zam-04 & $17.4^{\mathrm{c}}$ & $7.2^{\mathrm{b}}$ & $9.60^{c}$ & $2.3^{\mathrm{b}}$ & $43.3^{\mathrm{b}}$ & $31.9^{a}$ & $49.2^{\mathrm{b}}$ & $110^{\mathrm{bc}}$ \\
\hline \multicolumn{9}{|l|}{ Significance } \\
\hline SEM & 0.16 & 0.07 & 0.11 & 0.02 & 0.59 & 0.33 & 0.56 & 1.51 \\
\hline $\mathrm{P}$-value & $* * *$ & $* * *$ & $* * *$ & $* * *$ & $* * *$ & $* * *$ & $* * *$ & $* * *$ \\
\hline
\end{tabular}

In agreement with our findings large difference in the plant height among wheat genotypes were reported by Kim et al. (2016); 75.4 to $80.0 \mathrm{~cm}$ and Shahzad et al. (2002); 75 to $94 \mathrm{~cm}$. Plant height is directly proportion to biomass yield and nutritional quality of forages. Cultivars with more height have more long lean leaves proportion $(142-152 \mathrm{~cm})$, produces higher DM yields and more nutritious biomass of both forage and straw (Capstaff and Miller, 2018). In the present study, percentage of leaves varied from 33 to $45 \%$, which is consistent with the findings of Nasim et al. (2010), who reported large variation in the percentage of leaves (18 to 36\%) among wheat cultivars. Shahzad et al. (2002) recorded a similar variation (21 to 41\%) in the percentage of leaves among wheat genotypes. Leaves nutritional value is 3 times higher than the stem, as such cultivars with higher proportion of leaves and leaf: Stem ratio have higher nutritional value and digestibility.

Our result also showed large variation in nutrient composition and digestibility among the wheat cultivars, which can be used to design strategies for selection of high yielding and highly nutritious wheat genotypes for forage production and for their optimal feeding in animal rations. Although, many factors such as genotypes, maturity stage at harvest, growing condition and post-harvest management influences the chemical composition of forages (Bezabih et al., 2014; Khan et al., 2015b). In this study, the wheat genotypes were grown in twelve replicate plots under uniform growing and agronomic conditions and harvested at similar stage of maturity that provided excellent power for studying between-cultivars variations in nutrients composition and digestibility.
The large variation in chemical composition due to wheat genotypes can be used for improving the nutritional value of wheat forage through selection of wheat genotype with good nutritional characteristics such as those with high CP and lower NDF contents. Alternatively, wheat cultivars with high $\mathrm{CP}$ content and high DM digestibility will be the best choice.

The content of $\mathrm{CP}$ is the main index for forage quality assessment, particularly of grasses, because it influences animal intake, rumen fermentation efficiency and animal productivity, particularly in the small holding production systems, where animals receive very low or no concentrates (Khan et al., 2009, 2020). In our result, there was large variation in the content of $\mathrm{CP}$, ranging from 8.71 to $12.4 \%$ DM. Because of the potentially large daily consumption of forages, this variation in $\mathrm{CP}$ content will insert large impact on $\mathrm{CP}$ intake. The range of $\mathrm{CP}$ values observed in the present study is consistent with Kim and Anderson (2014) and Bezabih et al. (2018).

After $\mathrm{CP}$, the variation in NDF largely affects forage nutritional value. The NDF is used as a measure the cell walls content of forages, and it consist of cellulose, hemicellulose and lignin. The NDF content and degradability in the rumen are the major determinant of forage digestibility, DM intake and feed efficiency in dairy cows. The ADF content consist of cellulose and lignin, representing the less digestible fibre and it is negatively correlated with forage digestibility (Khan et al., 2015). There was large variation in the contents of NDF (42.4 to 44.7\%) and ADF (29.4 to $32.2 \%$ ) among the wheat cultivars in the present study. The variation in NDF content observed in our 
study is in line with findings of Kim et al. (2016), who observed marked variation in the NDF content (33.4 to $45.0 \%$ ) of wheat forage among 299 germplasm of wheat. Similarly, Bezabih et al. (2018) reported a wide range in the NDF content (70.6 to 76.6\%) among 25 wheat cultivars. Kim and Anderson (2014) also observed a wide range in the NDF content (39.4 to $46.5 \%)$ of wheat forage among 15 wheat cultivars. The variation in NDF content among the wheat cultivars may be related to the differences in leaf to stem ratios, as leaves contain lower content of NDF as compared to stem. Moreover, genotypes with long lean leaves contain lower content of NDF, and their forages are more digestible due less proportion of stem (Jung and Deetz, 1993). The large variation in chemical composition due to wheat genotypes highlights the huge scope for improving the nutritional value of wheat forage through selection of wheat genotype with good nutritional characteristics such as those with high $\mathrm{CP}$ and lower NDF content. Alternatively, wheat cultivars with high CP content and high DM digestibility will be the best choice.

For forages, digestibility is the single most important criteria for nutritional-quality evaluation. The digestibility of the forages not only determine the supply of nutrients to the animal, but is also the major determinant of feed intake, maintenance of rumen $\mathrm{pH}$ and milk fat content (Khan et al., 2015). Forages with higher digestibility support higher DM intake and supply more nutrients and energy per unit DM intake, and as such support more milk and meat production and vice versa. Forage digestibility can be affected by plant genotype, environment and maturity (Khan et al., 2020). In the present study, the wheat cultivars were evaluated under uniform conditions, and hence the variation in IVDMD reflect the genetic variation in digestibility. There was also large variation (48.5 to 58.9\%) in IVDMD of the wheat forages evaluated in the present study. In agreement with our findings Kim and Anderson (2014) recorded large variation (71.8 to $74.2 \%)$ in the IVDMD. Likewise, Bezabih et al. (2018) also reported large variation (46.4 to $483 \%$ ) in the IVDMD. The large variation in IVDMD due to wheat genotypes highlights the huge scope for improving the nutritional value of wheat forage through selection of wheat genotype with high IVDMD. Wheat cultivars with high IVDMD and high $\mathrm{CP}$ content will be the best choice for forage improvement.
The IVGP data measured through the fully automated gas production system over 72 hours incubation of forages in buffer rumen fluid (Figure 1), reflects the difference in their ruminal fermentation (rate and extent) among the grass species (Cone and Engles, 1996; He et al., 2020). The IVGP is mainly influenced by the chemical composition of the forages, particularly the $\mathrm{CP}$ and NDF content, but also by NDF composition such as the content of lignin (He et al., 2020). The NDF is least digestible (40 to 70\%) component of forages, whereas the digestibility of non-NDF components is very high (> 90\%) and less variable. Therefore, NDF content is the major determinant of forage digestibility (Bezabih et al., 2014), and hence IVGP. In this study wheat genotypes with higher content of $\mathrm{CP}$ and lower content of NDF such as cultivar Bakhtawar-92 and PS-15 produced the maximum rate of gas production and total IVGP, whereas those with the higher NDF and lower CP content, such as NARC11 produced lower rate of gas production and total IVGP. In agreement with our findings Kamalak et al. (2005) and Bezabih et al. (2014) reported that IVGP and IVDMD were negatively correlated with NDF and $\mathrm{ADF}$ and contents of forages, and positively correlated with CP content. These outcome shows that wheat cultivars with highest $\mathrm{CP}$ and lowest NDF values will support higher rate and extent, of rumen fermentation of $\mathrm{OM}$.

\section{Conclusions and Recommendations}

Significant genetic variation in forage biomass yield, morphological characteristic, forage nutritional value and digestibility were observed among five selected wheat genotypes. Bakhtawar-92 had maximum DM yield $(2747 \mathrm{~kg} / \mathrm{ha})$, proportion of leaves $(45 \%), \mathrm{CP}$ content (12.4\%), IVDMD (58.9\%) and IVGP (172 $\mathrm{mL} / \mathrm{g} \mathrm{OM})$, and lower contents of NDF (43.2\%) and ADF (30.2\%), which indicate good quality of wheat fodder. As such, Bakhtawar-92 is recommended for forage production based on higher forage DM yield, with lower content of NDF and higher $\mathrm{CP}$ content, IVGP and in vitro DM digestibility. Other cultivars which had similar desirable characteristic are placed in order of merit as PS-15, Ps-2000, Zam-04 and NARC-11. These findings highlight that genetic selection of wheat cultivars for forage production can be used for sustainable forage production during the winter feed scarcity periods. 
Acknowledgements

Authors very thankful for the financial and technical support of CIMMYT Pakistan under the Agriculture Innovation Program (AIP) of the USAID.

\section{Novelty Statement}

The selected cultivars are analysed for the first time for quality forge production and genetic variation in the forage quality trait.

\section{Author's Contribution}

Syed Muhammad Sulaiman: Investigation, conceptualization and writing, original draft.

Nazir Ahmad: Methodology, formal analysis, conceptualization, writing review and editing.

Nazir Ahmad Khan: Funding acquisition, supervision, conceptualization, and project administration.

\section{Conflict of interest}

The authors have declared no conflict of interest.

\section{References}

AOAC. 1995. Association of official analytical chemists, official methods of analysis, $15^{\text {th }}$ edition, AOAC, Arlington, VA, USA.

Bezabih, M., A. Adie, D. Ravi, K.V.S.V. Prasad, C. Jones, B. Abeyo, Z. Tadesse, H. Zegeye, T. Solomon and M. Blummel. 2018. Variations in food-fodder traits of bread wheat cultivars released for the Ethiopian highlands. Field Crops Res., 229: 1-7. https://doi.org/10.1016/j. fcr.2018.09.006

Bezabih, M., W.F. Pellikaan, A. Tolera, N.A. Khan and W.H. Hendriks. 2014. Chemical composition and in vitro total gas and methane production of forage species from the Mid Rift Valley grasslands of Ethiopia. Grass Forage Sci., 69: 635-643. https://doi.org/10.1111/ gfs.12091

Bisht, J.K., L. Kant and A.K. Srivastva. 2008. Cutting Management of dual purpose Wheat Cultivars. A new approach for increasing fodder availability. Cereal Res. Com., 36: 177-187. https://doi.org/10.1556/CRC.36.2008.1.18

Capstaff, N.M. and A.J. Miller. 2018. Improving the yield and nutritional quality of forage crops. Front Plant Sci., 9: 535. https://doi. org/10.3389/fpls.2018.00535

Cash, D., R. Carlstrom, L. Surber and A. Hafl. 2007. Forage yield and quality of 'Willow Creek' forage winter wheat. Montana State University Extension Service. Bozeman, USA.

Cone, J.W. and F.M. Engels. 1993. The influence of ageing on cell wall composition and degradability of three maize genotypes. Anim. Feed Sci. Tech., 4: 331-342. https://doi. org/10.1016/0377-8401(93)90062-O

Habib, G., M.F. Ullah, S. Javeed and M. Saleem. 2016. Assessment of feed supply and demand for livestock in Pakistan. J. Agri. Sci., A6: 191-202. https://doi.org/10.17265/21616256/2016.03.006

He, Y., J.W. Cone, W.H. Hendriks and J. Dijkstra. 2020. Relationships between chemical composition and in vitro gas production parameters of maize leaves and stems. J. Anim. Phys. Anim. Nutr., 104: 20-21. https://doi.org/10.1111/ jpn.13221

Jung, H.G., and D.A. Deetz 1993. Cell wall lignification and degradability. Forage cell wall structure and digestibility. pp. 315-346. https:// doi.org/10.2134/1993.foragecellwall.c13

Kamalak,A.D.E.M.,O.Canbolat,A.Erol,C.Kilinc, M. Kizilsimsek, C.O. Ozkan and E. Ozkose. 2005. Effect of variety on chemical composition, in vitro gas production, metabolizable energy and organic matter digestibility of alfalfa hays. Livest. Res. Rural Dev., 7: 1707-1712.

Khan, N.A., G. Habib and G. Ullah. 2009. Chemical composition, rumen degradability, protein utilization and lactation response to selected tree leaves as substitute of cottonseed cake in the diet of dairy goats. Anim. Feed Sci. Tech., 154: 160-168. https://doi.org/10.1016/j. anifeedsci.2009.08.011

Khan, N.A., S. Hussain, N. Ahmad, S. Alam, M. Bezabhi, W.H. Hendriks, P. Yu and J.W. Cone. 2015. Improving the feeding value of straws with Pleurotus ostreatus. Anim. Prod. Sci., 55: 241-245. https://doi.org/10.1071/AN14184

Khan, N.A., S.M. Sulaiman, M.S. Hashmi, S.U. Rahman and J.W. Cone. 2020. Chemical composition, ruminal degradation kinetics and methane production (in vitro) of winter grass species. J. Sci Food Agric., 101: 179-184. https://doi.org/10.1002/jsfa.10628

Kim, K.S. and J.D. Anderson. 2014. Forage yield and nutritive value of winter wheat varieties in 
the southern Great Plains. Euphytica, 14: 13251328.

Kim, K.S., J.D. Anderson, M.A. Newell and T.J. Butler. 2016. Variations of forage yield and nutritive value in winter rye germplasm. Crop Sci., 56: 1018-1024. https://doi.org/10.2135/ cropsci2015.08.0487

MacKown, C.T., B.F. Carver and J.T. Edwards. 2011. Variation in crude protein and in vitro dry matter digestion of wheat forage. Crop Sci., 51: 878-891. https://doi.org/10.2135/ cropsci2010.06.0319

Nasim, W., A. Ahmad, S.A. Wajid, A. Hussain, T. Khaliq, M. Usman, H.M. Hammad, S.R. Sultana, M. Mubeen and S. Ahmad. 2010. Simulation of different wheat cultivars under agro-ecological condition of Faisalabad-Pak. Crop Environ., 1: 44-48.

Northup, B.K.,J.A. Daniel and W.A. Phillips. 2010. Influences of agricultural practice and summer grazing on soil compaction in wheat paddocks. Am. Soc. Agric. Biol. Eng. 53: 405-411. https:// doi.org/10.13031/2013.29580

Shahzad, K., J. Bakht, W.A. Shah, M. Shafi and N.
Jabeen. 2002. Yield and yield components of various wheat cultivars as affected by different sowing dates. Asian J. Plant Sci., 5: 522-525. https://doi.org/10.3923/ajps.2002.522.525

Shuja, M.N., D. Nayab, M. Ali, A. Iqbal and I.H. Khalil. 2009. Evaluating the response of wheat genotypes to forage clipping. Int. J. Agric. Biol., 12: 111-114.

Sulaiman, S.M., N.A. Khan and N. Ahmad. 2021. Morphological characteristics and biomass yieldof fifteen novel germplasm of wheat for ruminant livestock, in Northern Pakistan. Int. J. Biol., 18: 145-149.

Tilley, J.M.A. and R.A. Terry. 1963. A two stage technique for the in vitro digestion of forage crops. Grass Forage Sci., 18: 104-111. https:// doi.org/10.1111/j.1365-2494.1963.tb00335.x

Van Soest, P.J., J.B. Robertson and B.A. Lewis. 1991. Methods for dietary fiber, neutral detergent fiber and non-starch polysaccharides in relation to animal nutrition. J. Dairy Sci., 73: 3583-3593. https://doi.org/10.3168/jds. S0022-0302(91)78551-2 